\title{
PENGUATAN USAHA MELALUI PENDAMPINGAN MENYUSUN LAPORAN KEUANGAN PADA BENGKEL "FIRA" DASAN LEKONG LOMBOK TIMUR
}

\author{
Isnawati ${ }^{1}$, Biana Adha Inapty ${ }^{2}$, Lukman Effendy ${ }^{3}$, Eni Indriani ${ }^{4}$ \\ Jurusan Akuntansi Fakultas Ekonomi Dan Bisnis Unram
}

Isnawati.isna@unram.ac.id

\begin{abstract}
ABSTRAK
Fakta pentingnya memiliki laporan keuangan bagi setiap perusahaan akan menjadi masalah ketika perusahaan memiliki sumber daya yang terbatas, dan hal itulah yang terjadi pada Bengkel "Fira". Solusi yang ditawarkan untuk pemecahan masalah yang dijelaskan di atas adalah dengan cara melakuakn pendampingan untuk membuat pembukuan yang baik dan lengkap, yaitu menyusun laporan keuangan. Harapannya nanti pemilik usaha bisa mengembangkan usahanya terus menerus melalui kemampuan mereka yang baik dalam memanajemen keuangannya yang dimulai dari kemampuan penyusunan laporan keuangan tersebut. Selain itu kegiatan pengabdian ini akan sangat bermanfaat bagi pemilik usaha untuk bisa mengembangkan usahanya, yang tentunya berimbas pada Program Pemerintah dalam hal pengentasan kemiskinan. Hasil dari kegiatan pengabdian ini akan dipublikasikan pada salah satu Jurnal pengabdian Kepada Masyarakat yang mana publikasi ini merupakan target luarannya.
\end{abstract}

Kata Kunci: Laporan Keuangan; Manajemen Keuangan; Perusahaan Jasa.

\begin{abstract}
The fact that it is important to have financial statements for every company will become a problem when the company has limited resources, and that is what happened to the "Fira" Workshop. The solution offered for solving the problems described above is by providing assistance to make good and complete bookkeeping, namely compiling financial reports. It is hoped that later business owners can develop their business continuously through their good ability in financial management starting from the ability to prepare financial statements. In addition, this service activity will be very useful for business owners to be able to develop their business, which of course has an impact on the Government Program in terms of poverty alleviation. The results of this service activity will be published in one of the community Service Journals where this publication is the output target.
\end{abstract}

Keyword: Financial statements; Financial management; Service Company 


\section{PENDAHULUAN}

\section{Latar Belakang}

Salah satu tujuan utama perusahaan atau organisasi bisnis adalah menghasilkan laba yang sebesar-besarnya, untuk itu perusahaan perlu menerapkan strategi yang tepat untuk mencapai sasaran tersebut. Salah satu faktor utama penentuan keberlangsungan perusahaan adalah pembukuan yang rapi. mendirikan usaha tanpa dukungan pembukuan yang baik dan terstruktur merupakan hal yang sia-sia. Hal ini bisa diibaratkan bagaikan prajurit maju perang tanpa membawa senjata, karena bisa menjauhkan kesuksesan walaupun entrepreneur memiliki teknik berbisnis yang andal. Dimana pembukuan yang baik merupakan senjata bagi perusahaan untuk mengambil keputusan ekonomis, seperti pengambangan pasar, penetapan tarif/harga, pembayaran gaji pegawai dan sebagainya.

Pembukuan ini dapat diartikan secara harfiah yaitu sebagai pencatatan transaksi keuangan oleh perorangan atau organisasi yang meliputi penjualan, pembelian, pendapatan dan pengeluaran. Menurut Undang-undang Perpajakan pasal 1 angka 26 Nomor 28 Tahun 2007 menyatakan bahwa pembukuan merupakan suatu proses pencatatan yang dilakukan secara teratur untuk mengumpulkan data dan informasi keuangan yang meliputi harta, kewajiban, modal, penghasilan, dan biaya, serta jumlah harga perolehan dan penyerahan barang atau jasa yang ditutup dengan menyusun laporan keuangan berupa neraca dan laporan laba rugi pada setiap tahun.

Begitu pentingnya manfaat dari pembukuan/penyusunan laporan keuangan ini, namun jarang sekali pengusaha yang menguasai system pembukuan ini. Kebanyakan diantara mereka mengandalkan pembukuan sederhana yang hanya mencatat pemasukan dan pengeluaran saja. Bahkan banyak pengusaha terutama dalam skala mikro yang sama sekali tidak memiliki catatan pembukuan untuk usahanya. 


\section{Jurnal ABDIMAS INDEPENDEN}

Vol. 2, No. 1, Mei 2021

Hal ini tentunya akan memberi kerugian tersendiri bagi pengusaha, dimana mereka tidak mengetahui berapa omset mereka secara tepat, berapa laba yang diperoleh, serta tidak mengetahui sama sekali keuntungan dari investasi peralatan yang telah dikeluarkan. Kondisi ini banyak terjadi di perusahaan khususnya usaha mikro, tidak terkecuali terjadi pula pada usaha Bengkel "Fira".

Bengkel "Fira" merupakan salah satu perusahaan jasa yang berlokasi di Dasan Lekong Kecamatan Sukamulia Kabupaten Lombok Timur. Usaha jasa tersebut bergerak dibidang penjualan jasa service (perbaikan mobil). Umumnya customernya berasal dari lingkungan sekitar Lombok Timur, tapi tidak menutup kemungkinan juga sesekali berasal dari Kota Mataram yaitu bagi mereka yang sudah nyaman untuk mempercayakan pemeliharaan mobilnya pada bengkel tersebut. Sejauh ini tidak terdapat pembukuan yang baik pada bengkel tersebut, padahal bisa dikatakan usaha tersebut sangat potensial untuk berkembang dikarenakan satu-satunya usaha bengkel yang ada di Desa tersebut, dan sejauh ini sudah memiliki banyak pelanggan. Perkembangan usaha ini bisa dikatakan cukup baik yang diperlihatkan dari yang semula tidak memiliki lahan usaha sendiri (sewa), sekarang sudah membuka usaha dilahan sendiri walaupun sebagian dengan pendanaan dari pihak ke tiga (Bank).

Fakta pembiayaan / pendanaan untuk pengadaan asset bengkel "Fira" yang bersumber dari perbankan menunjukkan bahwa usaha ini dipercaya memiliki omset yang jelas, apalagi diketahui dari pemilik bengkel sendiri bahwa pihak Bank sudah berkali-kali untuk menawarkan untuk melakukan konvensasi atas pembiayaan yang sudah berjalan sebelumnya. Akan tetapi dari pihak pemilik usaha sendiri belum berminat untuk menyetujui tawaran dari pihak pembiayaan tersebut. Hal ini dikarenakan bukan karena pihak pemilik usaha tidak berminat untuk mengembangkan usahanya, melainkan pemilik mendapatkan kesulitan untuk memenuhi salah satu syarat pembiayaan yang diminta yaitu laporan keuangan yang dimiliki oleh Bengkel "Fira" sebagai dasar untuk pihak pembiayaan menentukan besaran dana yang bisa dikonvensasikan pada bengkel tersebut. Hal 
tersebut menjadi salah satu penghambat Bengkel "Fira" untuk mengembangkan usahanya, terutama menambah persediaan suku cadang yang paling sering dibutuhkan seperti persediaan Oli. Sehingga sejauh ini Bengkel "Fira" lebih banyak memberikan jasa service dibandingkan penjualan suku cadang.

Berdasarkan fakta yang diuraikan tersebut, maka sangat penting bagi Bengkel "Fira" untuk memiliki pembukuan yang baik dan lengkap sebagai salah satu upayanya untuk mengembangkan usaha. Namun di satu sisi, kenyataan yang ada bahwa usaha mikro jarang memiliki sumber daya yang memadai, tidak terkecuali Bengkel "Fira". Tujuan pengabdian pada masyarakat ini adalah meningkatkan kemampuan pengusaha untuk mengatur keuagannya dengan cara memiliki pembukuan yang baik dan lengkap, yaitu pengusaha nantinya mampu menyusun laporan keuangannya sendiri. Dengan adanya kegiatan pengabdian pada masyarakat ini diharapkan dapat memberikan manfaat bagi pengusaha untuk bisa mengembangkan usahanya terus menerus melalui kemampuan mereka yang baik dalam memanajemen keuangannya yang dimulai dari kemampuan penyusunan laporan keuangan.

Bengkel "Fira" merupakan salah satu perusahaan jasa yang berlokasi di Dasan Lekong Kecamatan Sukamulia Kabupaten Lombok Timur. Usaha jasa tersebut bergerak dibidang penjualan jasa service (perbaikan mobil). Umumnya customernya berasal dari lingkungan sekitar Lombok Timur, tapi tidak menutup kemungkinan juga sesekali berasal dari Kota Mataram yaitu bagi mereka yang sudah nyaman untuk mempercayakan pemeliharaan mobilnya pada bengkel tersebut. Sejauh ini tidak memiliki pembukuan yang baik dan lengkap. Padahal tidak jarang laporan keuangan ini dibutuhkan terutama pada saat bersinggungan dengan pihak ke tiga seperti Lembaga pembiayaan yang menjadikan laporan keuangan sebagai salah satu syarat dalam pengajuan pembiayaan dalam skala besar. Hal inilah yang membuat Bengkel "Fira" belum bisa mengembangkan usahanya lebih besar lagi, karena sejauh ini hanya bisa menerima pendanaan yang kecil, yaitu pendanaan yang tidak membutuhkan laporan keuangan sebagai salah satu persyaratan pendanaan. Fakta pentingnya memiliki laporan keuangan bagi 


\section{Jurnal ABDIMAS INDEPENDEN}

Vol. 2, No. 1, Mei 2021

setiap perusahaan akan menjadi masalah ketika perusahaan memiliki sumber daya yang terbatas, dan hal itulah yang terjadi pada Bengkel "Fira". Oleh karena itu dirasakan sangat perlu melakukan pendampingan untuk membuat pembukuan yang baik dan lengkap, yaitu pendampingan menyusun laporan keuangan. untuk mewujudkan itu, maka dilakukan kegiatan pengabdian pada masyarakat dengan judul "Penguatan Usaha Melalui Pendampingan Menyusun Laporan Keuangan pada Bengkel “Fira” Dasan Lekong Lombok Timur.

\section{METODE KEGIATAN}

Metode yang digunakan dalam kegiatan pengabdian masyarakat ini untuk mencapai tujuan yang telah dirumuskan di awal adalah sebagai berikut:

1. Pertama-tama melakukan evaluasi untuk system pembukuan yang digunakan selama ini oleh Bengkel "Fira" untuk mengetahui kekurangan dari pembukuan tersebut. Serta sebagai dasar materi pendampingan yang akan dilakukan nantinya.

2. Setelah melakukan evaluasi, selanjutnya dilakukan proses sosialisasi untuk memberikan pemahaman ke pemilik usaha akan pentingnya pembukuan atas keuangan usahanya. Selain itu juga memberikan penjelasan tentang model pembukuan yang baik, yaitu pembukuan yang bisa memberikan gambaran keuangan perusahaan secara menyeluruh.

3. Melakukan pendampingan pemilik dan bagian administrasinya Bengkel "Fira" dalam hal penyusunan laporan keuangan. Dimulai dengan mendampingi bagian administrasi untuk membuat pembukuan sederhana yang meliputi:

- Buku Kas Masuk

- Buku Kas Keluar

- Laba Rugi

- Neraca 


\section{HASIL DAN PEMBAHASAN}

Kegiatan pengabdian sudah terlaksana dengan beberapa tahapan sebagai berikut:

\section{- Tahap Evaluasi}

Tahapan pertama yaitu melakukan evaluasi untuk system pembukuan yang digunakan selama ini oleh Bengkel "Fira" untuk mengetahui kekurangan dari pembukuan tersebut. Serta sebagai dasar materi pendampingan yang akan dilakukan nantinya. Kegiatan evaluasi dilakukan dengan melakukan kunjungan secara langsung ke Bengkel "Fira" yang beralamatkan di Desa Dasan Lekong Kabuptaen Lombok Timur. Kunjungan ini dilaksanakan setelah Isu Covid 19 tidak separah pada awal-awal bulan maret 2020, tepatnya pada hari minggu tanggal 6 September 2020. Kunjungan dilakukan oleh salah satu tim pengabdian, mengingat masih terdapat himbauan untuk menghindari kerumunan. Kunjungan ini dilakukan oleh tim yang bernama Isnawati. Hasil dari kunjungan ini menemukan bahwa Bengkel "Fira" sama sekali tidak melakukan pembukuan dengan baik dan tertata rapi. Kalaupun ada catatan yang dilakukan, catatan tercecer kesana kemari. Nota-nota tidak disimpan dengan baik. Berdasarkan hasil temuan pada tahap evaluasi ini, maka dilanjutkan ke proses berikutnya.

\section{- Tahap Sosialisasi}

Berdasarkan hasil temuan pada tahap evaluasi pembukuan yang digunakan oleh Bengkel "Fira", dimana Bengkel tersebut sama sekali tidak memiliki pembukuan yang baik untuk keuangannya, maka langkah selanjutnya adalah meberikan ceramah atau penjelasan tentang apa dan bagaimana pembukuan itu. Mulai dari memberikan penjelasan tentang ap aitu pembukuan?, apa keguanaan pembukuan?, bagaimana bentuk sederhana pembukuan?.

Tahapan pemberian materi pembukuan sederhana ini juga dilakukan oleh salah satu tim mengingat adanya himbauan pemerintah untuk tidak membuat kerumunan. Namun bukan berarti anggota tim yang lain tidak memiliki porsii tugas apapun. Tim yang tidak kebagian untuk melakukan kunjungan langsung 


\section{Jurnal ABDIMAS INDEPENDEN}

Vol. 2, No. 1, Mei 2021

ke lokasi kegiatan pengabdian (mitra) berkewajiban untuk menyiapkan bahan atau materi tentang pembukuan sederhana. Materi ini dibuat dalam bentuk modul sederhana untuk dibagikan ke mitra pengabdian agar memudahkan tim dalam memberikan pemahaman ke pemilik usaha tentang hal-hal yang berkaitan dengan pembukuan sederhana. Tim yang bertugas untuk menyiapkan materi ini adalah Ibu Eni Indriani, sedangkan tim yang lainnya bertugas untuk Menyusun laporan akhir dari kegiatan Pengabdian Kepada Masyarakat (PKM) ini. Adapun yang bertugas untuk menjelaskan materi pembukuan sederhana tersebut adalah tetap bu Isnawati, karena sudah ada kontak sebelumnya pada tahap evaluasi dengan pemilik usaha, maka bisa memudahkan tahap berikutnya. Tahap ke dua ini dilaksanakan pada hari Minggu 20 September 2020. Adapun materi modul pembukuan sederhana yang dijelaskan ke mitra bisa dilihat pada lampiran.

\section{- Tahap Pendampingan}

Setelah tahapan penjelasan materi tentang pembukuan sederhana ke mitra dilakukan, maka tahapan berikutnya adalah melakukan pendampingan untuk membuat pembukuan sederhana oleh Bengkel "Fira". Tahapan pendampingan ini dilakukan untuk memastikan bahwa pemilik usaha bisa Menyusun/membuat sendiri pembukuan usahanya. Kegiatan pendampingan ini dilakukan sebanyak dua (2) kali yaitu pada hari Sabtu 25 September 2020 dan pada hari minggu 27 September 2020. Kegiatan pendampingan dilakukan menggunakan media telepon.

\section{SIMPULAN DAN SARAN}

Kegiatan Pengabdian Kepada Masayarakat dilakukan melului tiga tahapan yaitu, tahap evaluasi, tahap sosialisasi dan tahap pendampingan. Kegiatan evaluasi dilakukan dengan melakukan kunjungan secara langsung ke Bengkel "Fira" yang beralamatkan di Desa Dasan Lekong Kabuptaen Lombok Timur. Kunjungan ini dilaksanakan setelah Isu Covid 19 tidak separah pada awal-awal bulan maret 2020, 
tepatnya pada hari minggu tanggal 6 September 2020. Berdasarkan hasil temuan pada tahap evaluasi pembukuan yang digunakan oleh Bengkel "Fira", dimana Bengkel tersebut sama sekali tidak memiliki pembukuan yang baik untuk keuangannya, maka langkah selanjutnya adalah meberikan ceramah atau penjelasan tentang apa dan bagaimana pembukuan itu. Mulai dari memberikan penjelasan tentang ap aitu pembukuan?, apa keguanaan pembukuan?, bagaimana bentuk sederhana pembukuan?. Setelah tahapan penjelasan materi tentang pembukuan sederhana ke mitra dilakukan, maka tahapan berikutnya adalah melakukan pendampingan untuk membuat pembukuan sederhana oleh Bengkel "Fira". Tahapan pendampingan ini dilakukan untuk memastikan bahwa pemilik usaha bisa Menyusun/membuat sendiri pembukuan usahanya. Kegiatan pendampingan ini dilakukan sebanyak dua (2) kali yaitu pada hari Sabtu 25 September 2020 dan pada hari minggu 27 September 2020. Kegiatan pendampingan dilakukan menggunakan media telepon.

\section{UCAPAN TERIMA KASIH}

Pelaksanaan kegiatan Pengabdian Kepada Masyarakat ini telah melibatkan berbagai pihak, oleh karena itu pada kesempatan ini kami mengucapkan terima kasih dan penghargaan kepada :

1 LPPM UNRAM selaku koordinator pelaksanaan pengabdian kepada masyarakat.

2 Fakultas Ekonomi dan Bisnis Universitas Mataram dan BP2EB Fakultas Ekonomi dan Bisnis Universitas Mataram.

3 Karyawan Bengkel Fira Lombok Timur.

\section{DAFTAR PUSTAKA}

Bagusspi.blog.unair.ac.id tertanggal 12 Nopember 2008

Garrison, Ray H and Noreen Eric W., (2003) Managerial Accounting, 10th Edition, McGraw Hill Companies, Inc, New York. 


\section{Jurnal ABDIMAS INDEPENDEN}

Vol. 2, No. 1, Mei 2021

Hilton, Ronald W., and David E Platt., (2011) Managerial Accounting, 9th Edition, McGraw Hill Companies, Inc, New York.

http://dreamindonesia.wordpress.com. Tertanggal 27 Maret 2011

Kotler, Philip, (1997), Marketing Management, 9th Edition, Prentice Hall.

Mulyadi., (2001), Akuntansi Manajemen: Konsep,Manfaat \& Rekayasa,Cetakan 3, Edisi 3,Salemba Empat, Jakarta.

Supriyono, R.A., (2001), Akuntansi Manajemen 3: Proses Pengendalian Manajemen, Edisi Pertama, Cetakan Pertama, BPFE, Yogyakarta.

Undang-Undang perpajakan Pasal 1 angka 26 Nomor 28 Tahun 2007 tentang ketentuan umum dann tata cara perpajakan 
Lampiran 1 : Laporan Keuangan

\section{BENGKEL FIRA}

Perhitungan Laba-Rugi

Untuk Periode Yang Berakhir 30 Septemner 2020

Pendapatan

1. Pendapatan

2. Pendapatan Komisi

Rp. 7.150.000,00

Rp. $400.000,00+$

Rp. 7.550.000,00

Beban - beban

1. Beban Gaji

2. Beban Perlengkapan

3. Beban Bunga

4. Beban Listrik dan Telepon

5. Beban Sewa Alat

6. Beban Penyusutan Bangunan

7. Beban Lain-Lain

Rp. $3.550 .000,00$

Rp. $\quad 500.000,00$

Rp. $\quad 250.000,00$

Rp. $\quad 300.000,00$

Rp. $400.000,00$

Rp. $\quad 200.000,00$

Rp. $\quad 500.000,00$

Laba bersih 


\section{Jurnal ABDIMAS INDEPENDEN}

Vol. 2, No. 1, Mei 2021

BENGKEL FIRA

Neraca

31 Desember 2019

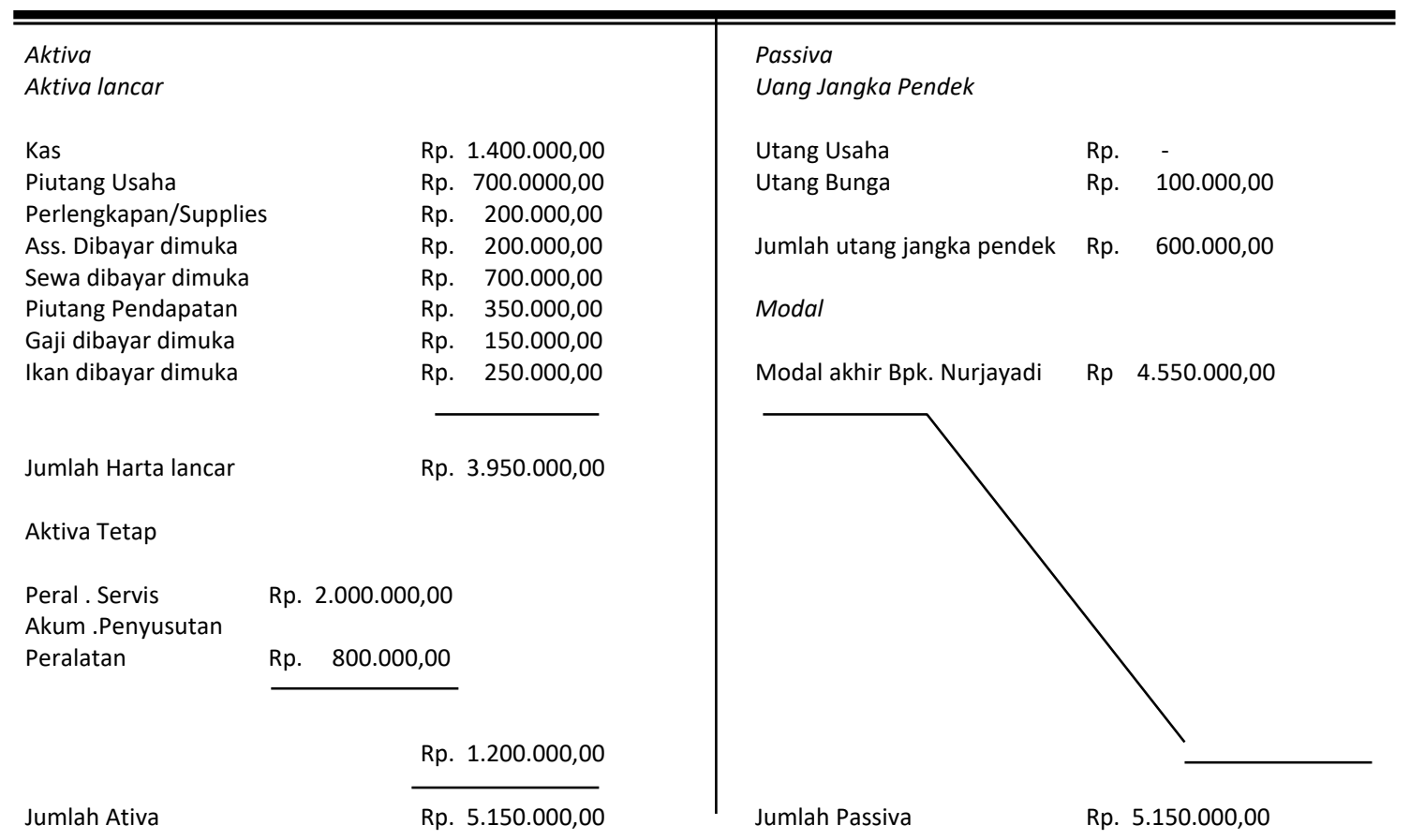

Lampiran 2: Peta Lokasi Kegiatan PKM

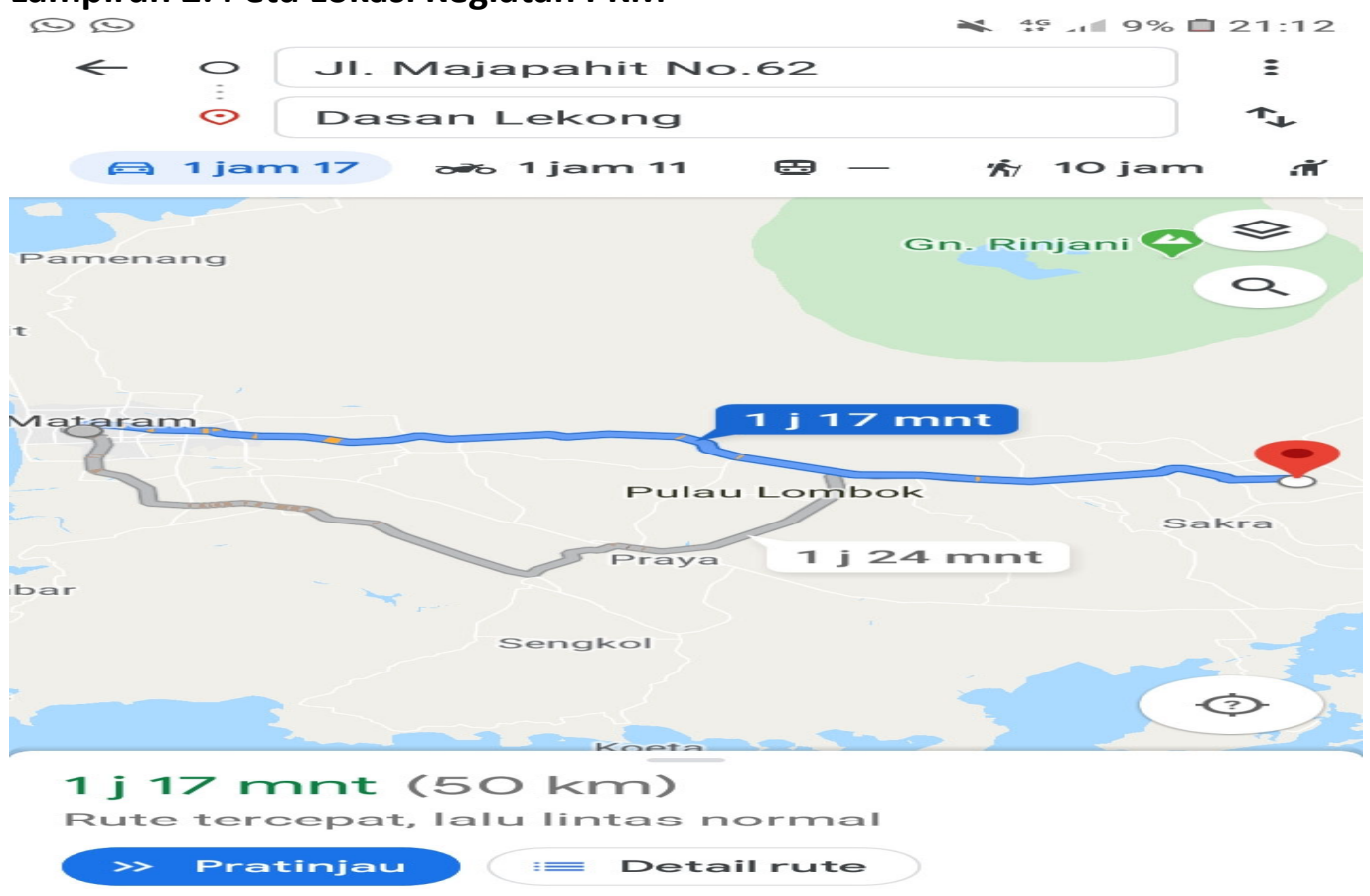


Lampiran 3: Dokumentasi Kegiatan Pengabdian Kepada Masyarakat

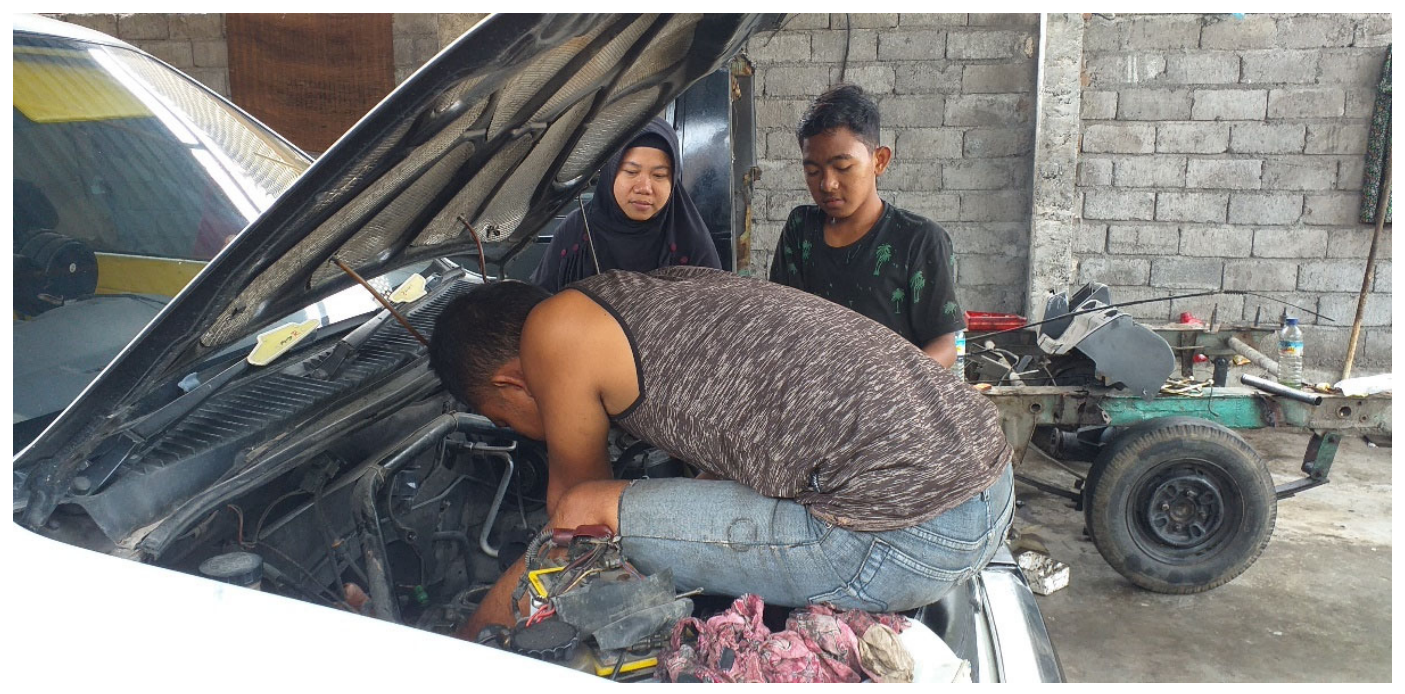

